University of Nebraska - Lincoln

DigitalCommons@University of Nebraska - Lincoln

Faculty Publications: Department of Entomology

October 1982

\title{
Damage Potential of Adult and Larval Southern Corn Billbugs (Coleoptera: Curculionidae) on Field Corn in Eastern North
} Carolina

\author{
Robert J. Wright \\ University of Nebraska-Lincoln, rwright2@unl.edu \\ J. W. Van Duyn \\ North Carolina State University \\ J. R. Bradley Jr. \\ North Carolina State University
}

Follow this and additional works at: https://digitalcommons.unl.edu/entomologyfacpub

Part of the Entomology Commons

Wright, Robert J.; Van Duyn, J. W.; and Bradley, J. R. Jr., "Damage Potential of Adult and Larval Southern Corn Billbugs (Coleoptera: Curculionidae) on Field Corn in Eastern North Carolina" (1982). Faculty Publications: Department of Entomology. 92.

https://digitalcommons.unl.edu/entomologyfacpub/92

This Article is brought to you for free and open access by the Entomology, Department of at DigitalCommons@University of Nebraska - Lincoln. It has been accepted for inclusion in Faculty Publications: Department of Entomology by an authorized administrator of DigitalCommons@University of Nebraska - Lincoln. 


\title{
Damage Potential of Adult and Larval Southern Corn Billbugs (Coleoptera: Curculionidae) on Field Corn in Eastern North Carolina ${ }^{1}$
}

\author{
R. J. WRIGHT, ${ }^{2}$ J. W. VAN DUYN, AND J. R. BRADLEY, JR. \\ Department of Entomology, North Carolina State University, Raleigh, North Carolina 27650 \\ ABSTRACT
}

J. Econ. Entomol. 75: 872-876 (1982)

Adult and larval damage potential of the southern corn billbug (SCB), Sphenophorus callosus (Olivier), was studied in small-plot enclosures and in commercial cornfields in eastem North Carolina from 1978 to 1980. In small-plot studies, corn at the two- and four-leaf stages showed damage by adult SCB at several insect densities, but more mature com was not visibly damaged. Female SCB caused more damage than male SCB on three- to four-leaf stage corn. Damage by females tended to result in dead terminals, whereas feeding by males more often resulted in holes in the leaves.

In small-plot studies, average plant height per plot was negatively correlated with average damage ratings per plot on three dates in 1980 on whorl stage corn. However, grain yield per plot at harvest was positively correlated with average damage ratings per plot on 9- to 10-leaf stage corn.

In commercial cornfields, larval SCB infestations were often associated with early death in corn plants. Of a total of 506 plants sampled at two sites in late July and early August 1980, 85.2\% of plants dying early were infested with larval SCB, whereas nondying plants had $10.0 \%$ SCB infestations. This early death was associated with a $42.4 \%$ yield decrease in paired comparisons of adjacent dying and nondying plants. The southern cornstalk borer, Diatraea crambidoides (Grote), was the only other insect found in large numbers in the lower cornstalk region. However, its presence was not well related to the incidence of early death.

The southern corn billbug (SCB), Sphenophorus callosus (Olivier), is a major insect pest of corn in the Coastal Plain region of North Carolina. Adults feeding on seedling corn will frequently kill the plant, whereas adults feeding on later stages may damage or kill the main shoot. Sublethal effects of adult feeding include deformed plant parts, suckering, and a characteristic pattern of round holes across emerged leaves (Webster 1912, Metcalf 1917).

Early researchers recommended early planting, proper drainage, fertilization, liming, and crop rotation as control practices because these practices reduced the degree of overlap between susceptible corn plant stages and SCB adult activity (Webster 1912, Metcalf 1917). However, until recently, no one has studied the relationship between corn plant damage and the intensity and timing of adult SCB attack. Durant (1981) reported on the effect of both com plant stage and SCB adult density on corn plant survival, height, and grain yield.

Additionally, larval SCB tunneling in the stalk base was reported to reduce plant yield and growth (Webster 1912, Metcalf 1917), yet it has not been studied quantitatively.

Reported here are studies conducted to provide information on factors affecting damage to corn by adult and larval SCB feeding for the improvement of SCB management programs.

\section{Materials and Methods Adult Damage Potential}

A grid of sixty-four square enclosures ( 1.8 by $1.8 \mathrm{~m}$ ) of sheet aluminum sections was constructed in 1978 at

'Received for publication 16 November 1981. Paper no. 8068 of the Joumal Series of the N.C. Agric. Res. Serv., Raleigh, N.C.

2Present address: Comell University, Long Island Horticultural Research Lab, 39 Sound Ave., Riverhead, NY 11901. the Tidewater Research Station (TRS), Plymouth, N.C. The sheet aluminum sections provided a barrier between enclosures ca. $30 \mathrm{~cm}$ above ground and $10 \mathrm{~cm}$ below ground. SCB do not fly readily (Wright 1981) and this barrier effectively isolated each enclosure from the others. In 1978 to 1980 , factorial experiments with a randomized complete block design were conducted within the enclosures. Four plant growth stages (two-, four-, six-, and eight-leaf stages [Hanway 1966]) and four adult SCB densities (1:1 sex ratio) were used, i.e., 0, 2, 4, and 8 SCB per 35 plants (1978), 0, 4, 8, and 16 SCB per 35 plants (1979), and $0,4,8$, and 16 SCB per 25 plants (1980). Releases of field-collected SCB were made as plants reached the indicated growth stage.

Pioneer brand 3535 field corn was planted on 10 June 1978, 10 May 1979 and 30 May 1980. All agronomic practices such as fertilization and herbicide use were as commonly performed for field corn and were applied uniformly within blocks. Corn was planted ca. $50 \%$ over the desired density; before SCB release in each plot, plants were thinned to the desired density. In 1979 to 1980 , two rows of corn were planted around the outside of the enclosures to serve as guard rows. Grain was hand-harvested from all plants in each plot (1979 to 1980 ), and yield was measured as shelled grain weight (15.5\% moisture) per plot.

After all SCB had been released and corn was in the 9- to 10-leaf stage, damage was rated as number of plants with leaf hole damage, or deformed or dead terminal growth (1978 to 1979). In 1980, plants were rated by a damage rating scale: $0=$ no damage; 1 = leaf hole damage only; 2 = deformed growth, or suckering; and $3=$ death of terminal growth. Ratings were made after SCB had been released in plots on 17 and 25 June and 3 and 9 July corresponding to 4-, 6-, 8-, and 9- to 10leaf stages, respectively. Plant heights were measured 
on 25 June and 3 and 9 July as distance from plant base to tip of longest leaf held vertically. Larval SCB infestations were not evaluated (1978 to 1980).

Data were analyzed by analysis of variance, Duncan's multiple range test, regression and correlation analyses.

\section{Sex Effects}

Three tests were conducted in 1979 at TRS to determine if adult SCB damage potential was affected by SCB sex. In all experiments, Pioneer brand 3184 corn was planted inside small plot enclosures (ca. $3 \mathrm{~m}$ in diameter, $30 \mathrm{~cm}$ tall) made from fiber glass hoops.

Test 1.-Five male or five female SCB were released in each of four enclosures containing six three-leaf stage corn plants on 13 June. Plants were rated for damage on 26 June.

Test 2.-Ten male or 10 female SCB were released in each of four enclosures containing ten four-leaf stage corn plants on 8 June. Plants were rated for damage on 20 June and on 9 July.

Test 3.-Five male or five female SCB were released in each of seven plots containing 8 to 10 corn plants at the four-leaf stage on 20 June. Plants were rated for damage on 26 June.

\section{Larval Damage}

Previous observations indicated that larval SCB-infested com plants could be identified easily after tasselling because they tended to die earlier than noninfested plants, and early death appeared to be associated with reduced yield. Studies were conducted to determine the degree of association of SCB larvae with early death and yield reduction in corn.

In a SCB-infested cornfield near Cherry, Washington County, N.C., 38 and 60 plants showing signs of early death (i.e., leaves yellowing and drying up) were tagged and paired with adjacent nondying plants on 25 July and 1 August 1980, respectively. Corn was in early dent stage at this time. Grain was hand harvested at maturity, the lower $30 \mathrm{~cm}$ of the stalks were split, and evidence of insect larval feeding or presence was recorded. Paired comparisons of yield were analyzed with Student's $t$ test.

To further test the association between early death and the presence of SCB larvae, two sets of 100 and 75 plants were sampled at random throughout the field on 23 July 1980 at the Washington County site. Plants were rated for early death, the lower $30 \mathrm{~cm}$ of stalk split, and presence or evidence of insect larval feeding was recorded. Similar studies were conducted at a SCB-infested commercial cornfield in Tyrrell County, N.C. on late-milk stage corn. Two groups of 100 and 75 plants were rated and examined as before on 23 to 24 July 1980.

\section{Results \\ Adult Damage Potential}

Early-season damage.-Number of damaged plants, excluding leaf hole damage, in 1978 was greatest at the two- and four-leaf stages at the highest SCB density studied. These were the only treatment combinations with damage significantly greater than in the uninfested controls (Table 1). Damaged plants, including leaf hole damage (the least severe damage type), responded similarly to SCB density and com plant stage (Wright 1981).

There was a low level of SCB damage in the uninfested plots. This could be due to interchange between plots or to a low density of SCB at the experimental site before $\mathrm{SCB}$ release. However, the small-plot enclosures did restrict SCB movement enough to establish different densities in the plots, as evidenced by differences in plant damage (Table 1).

In 1979, the SCB density levels were confounded by a resident SCB population which overwintered in some of the study plots from 1978. This accounted for the higher damage in the uninfested control plots in 1979. However, the 1979 results showed that at the highest SCB density, damage significantly greater than the uninfested control occurred only at the two- and four-leaf stages (Table 2).

In 1980 , the results of mean damage ratings of the plots were similar to those observed in 1978 and 1979. Damage significantly greater than that in the uninfested controls occurred only in the two- and four-leaf stages (Table 3).

Effects on Plant Growth and Yield.-In 1979, yield significantly less than the uninfested controls occurred only at the highest SCB density (16 SCB) released on two-leaf stage corn (507.9 vs. 1132.4 to $1365.5 \mathrm{~g}$ of shelled corn per plot, $15.5 \%$ moisture).

In the 1980 damage potential experiment, corn plant heights on three dates, 25 June and 3 and 9 July, corresponding to 6-, 8-, and 9- to 10-leaf stages, respectively, were significantly affected by plant stage at the time of SCB release, adult SCB density, and plant stage $\times$ SCB density interaction ( $F$ test, $p<0.01$ for all effects). On all three dates, there were significant negative correlations between average plant heights per plot and average SCB damage rating values per plot for each date 25 June, $r=-0.803,40 \mathrm{df}, 3 \mathrm{July}, \mathrm{r}=-0.872$, $50 \mathrm{df}$, and $9 \mathrm{July}, \mathrm{r}=-0.780,63 \mathrm{df}, P<0.01$ for all $r$ values).

However, for yields in 1980, there were no significant main effects due to plant stage at time of SCB release or adult SCB density. The plant stage $\times$ SCB density interaction was significant $(p<0.03)$, but there was only one treatment mean significantly different from all other treatment combinations. Eight SCB released at the four-leaf stage resulted in the highest yield of all treatments (665.5 vs. 91.1 to $372.6 \mathrm{~g}$ of shelled corn plot, $15.5 \%$ moisture). Also, average plant damage ratings per plot taken on 9 July 1980 on 9- to 10-leaf stage corn, were positively correlated with grain yield per plot $(\mathrm{r}=+0.390,63 \mathrm{df} P<0.01)$ (i.e., plots with greater average SCB damage ratings had higher yields).

\section{Sex Effects}

Overall, damage from feeding by adult females was more severe than that from adult males. In two of three 
Table 1.-Number of plants damaged by SCB adults (excluding leaf hole damage) released at indicated SCB density and corn plant stage, Tidewater Research Station, Plymouth, N.C., 1978

\begin{tabular}{cllll}
\hline \hline & \multicolumn{3}{c}{ SCB density $b / 35$ plants } \\
\cline { 2 - 5 } Com plante stage & 0 & 2 & 4. & 8 \\
\hline 2 leaves & $0.2 \mathrm{~d}^{r}$ & $4.8 \mathrm{bc}$ & $4.8 \mathrm{bc}$ & $9.3 \mathrm{a}$ \\
4 leaves & $0.8 \mathrm{c}$ & $2.8 \mathrm{c}$ & $2.0 \mathrm{c}$ & $7.0 \mathrm{ab}$ \\
6 leaves & $0.2 \mathrm{~d}$ & $1.5 \mathrm{c}$ & $0.0 \mathrm{~d}$ & $1.0 \mathrm{c}$ \\
8 leaves & $0.0 \mathrm{~d}$ & $0.2 \mathrm{~d}$ & $0.0 \mathrm{~d}$ & $0.8 \mathrm{c}$ \\
Avg uninfested control & 0.3 & & & \\
\hline
\end{tabular}

${ }^{a}$ Corn plant stages based on Hanway (1966).

${ }^{b}$ Billbugs released in $1: 1$ sex ratio.

'Means followed by the same letter for all treatment combinations are not significantly different $(0.05$ level). Duncan's multiple range test.

Table 2.-Number of plants damaged by SCB (all damage types) released at indicated corn plant stages and billbug densities, Tidewater Research Station, Plymouth, N.C., 1979

\begin{tabular}{clccc}
\hline & & \multicolumn{2}{c}{ SCB density $/ 35$ plants } \\
\cline { 2 - 5 } Corn plant stage & 0 & 4 & 8 & 16 \\
\hline 2 leaves & $4.2 \mathrm{bc}$ & $6.5 \mathrm{bc}$ & $8.8 \mathrm{~b}$ & $19.3 \mathrm{a}$ \\
4 leaves & $0.0 \mathrm{c}$ & $5.8 \mathrm{bc}$ & $5.0 \mathrm{bc}$ & $9.0 \mathrm{~b}$ \\
6 leaves & $2.3 \mathrm{bc}$ & $3.3 \mathrm{bc}$ & $3.5 \mathrm{bc}$ & $1.8 \mathrm{c}$ \\
8 leaves & $1.5 \mathrm{c}$ & $3.3 \mathrm{bc}$ & $0.8 \mathrm{c}$ & $0.5 \mathrm{c}$ \\
Avg uninfested control & 2.0 & & & \\
& & & &
\end{tabular}

aSCB released in 1:1 sex ratio.

'Means of all treatment combinations followed by the same letter are not significantly different $(0.05$ level), Duncan's multiple range test.

Table 3.-Mean damage rating per 25 plants after SCB were released at indicated corn plant stages and SCB densities, Tidewater Research Station, Plymouth, N.C., 1980

\begin{tabular}{cllll}
\hline \hline & & \multicolumn{2}{c}{ SCB density/25 plants } \\
\cline { 2 - 5 } Corn leaf stage & \multicolumn{1}{c}{0} & 4 & 8 & 16 \\
\hline 2 leaves & $0.08 \mathrm{e}^{\mathrm{r}}$ & $0.22 \mathrm{de}$ & $0.43 \mathrm{~cd}$ & $0.95 \mathrm{a}$ \\
4 leaves & $0.01 \mathrm{e}$ & $0.38 \mathrm{~cd}$ & $0.76 \mathrm{ab}$ & $0.65 \mathrm{bc}$ \\
6 leaves & $0.02 \mathrm{e}$ & $0.09 \mathrm{e}$ & $0.11 \mathrm{e}$ & $0.03 \mathrm{e}$ \\
8 leaves & $0.01 \mathrm{e}$ & $0.01 \mathrm{e}$ & $0.07 \mathrm{e}$ & \\
Avg uninfested control & 0.03 & & &
\end{tabular}

aPlants rated 9 July at 9- to 10 -leaf stage based on damage rating scale: $0=$ no damage; $1=$ leaf hole damage only; $2=$ deformed growth or suckering; and 3 = dead terminal growth.

bSCB released in 1:1 sex ratio.

'Means of all treatment combinations followed by the same letter are not significantly different $(0.05$ level), Duncan's multiple range test.

tests, mean damage ratings of plants exposed to female SCB were significantly greater than that of plants exposed to male SCB (Table 4). Damage by females tended to result in a greater incidence of dead terminals, whereas feeding by males more often resulted in leaf hole damage only (Table 4).

Plants rated on two dates after exposure to SCB showed that damage by females was of a more severe nature. These plants were less likely to recover than plants fed on by males (Table 4).

\section{Larval Damage}

In six trials at two sites, a total of 506 plants was rated for early death, stalks were split, and SCB presence or evidence of SCB larval feeding damage was recorded. Of 215 plants dying early (D), $85.2 \%$ were infested with SCB or had evidence of larval feeding corresponding to that of at least a large larva ( $>3$ rd instar). Of 291 plants not dying early (ND), $10.0 \%$ were infested with SCB as defined before (Table 5).

At the Washington County site, the mean yield decrease per plant on two dates, comparing $D$ to $N D$, was 80.0 and $75.6 \mathrm{~g}$ of shelled corn (15.5\% moisture), equivalent to a 44.0 and $40.8 \%$ yield reduction, respectively.

Southern cornstalk borer (SCSB) larvae, Diatraea crambidoides (Grote), were the only other major stalk boring insects found in the stalk base. In the two trials for which yield data were taken, 39.5 and $58.3 \%$ of ND plants and 7.9 and $23.3 \%$ of D plants were infested with SCSB larvae (Table 5). Over all six trials, the pattern 
Table 4.- Number of corn plants damaged by SCB released on three- to four-leaf stage corn, Tidewater Research Station, Plymouth, N.C., 1979

\begin{tabular}{|c|c|c|c|c|c|c|c|c|}
\hline \multirow[b]{4}{*}{ Damage category } & \multicolumn{8}{|c|}{ No. of plants in indicated damage category: } \\
\hline & \multicolumn{2}{|c|}{ Test $1^{a}$} & \multicolumn{4}{|c|}{ Test $2^{a}$} & \multicolumn{2}{|c|}{ Test $3^{a}$} \\
\hline & \multirow[b]{2}{*}{$\delta^{b}$} & \multirow[b]{2}{*}{$\phi^{b}$} & \multicolumn{2}{|c|}{$\begin{array}{c}\text { Plants Rated } \\
20 \text { June }\end{array}$} & \multicolumn{2}{|c|}{$\begin{array}{l}\text { Plants Rated } \\
9 \text { July }\end{array}$} & \multirow[b]{2}{*}{$\delta$} & \multirow[b]{2}{*}{$q$} \\
\hline & & & $\delta$ & 운 & $\delta$ & q & & \\
\hline Dead terminal growth & 4 & 12 & 0 & 2 & 0 & 2 & 5 & 7 \\
\hline Deformed growth & 0 & 0 & 7 & 17 & 6 & 9 & 0 & 0 \\
\hline Suckering & 1 & 0 & 0 & 0 & 1 & 1 & 0 & 0 \\
\hline Leaf holes & 3 & 0 & 10 & 3 & 0 & 0 & 26 & 9 \\
\hline No damage & 4 & 0 & 3 & 0 & 13 & 8 & 7 & 10 \\
\hline Mean damage rating & $1.42 *$ & 3.00 & $1.20^{*}$ & 1.95 & $0.65^{*}$ & 1.30 & 1.08 & 1.15 \\
\hline
\end{tabular}

${ }^{a}$ Details of test procedures in text.

bSCB sex

'Damage rating scale: $0=$ no damage; $1=$ leaf hole damage only; $2=$ deformed growth or suckering; and $3=$ terminal growth dead. *, Significant difference between pair of means, by Student's $t$ test, 0.05 level.

Table 5.-Relationship of two stalk-boring insects to early death of field corn, Washington and Tyrrell Counties, N.C., 1980

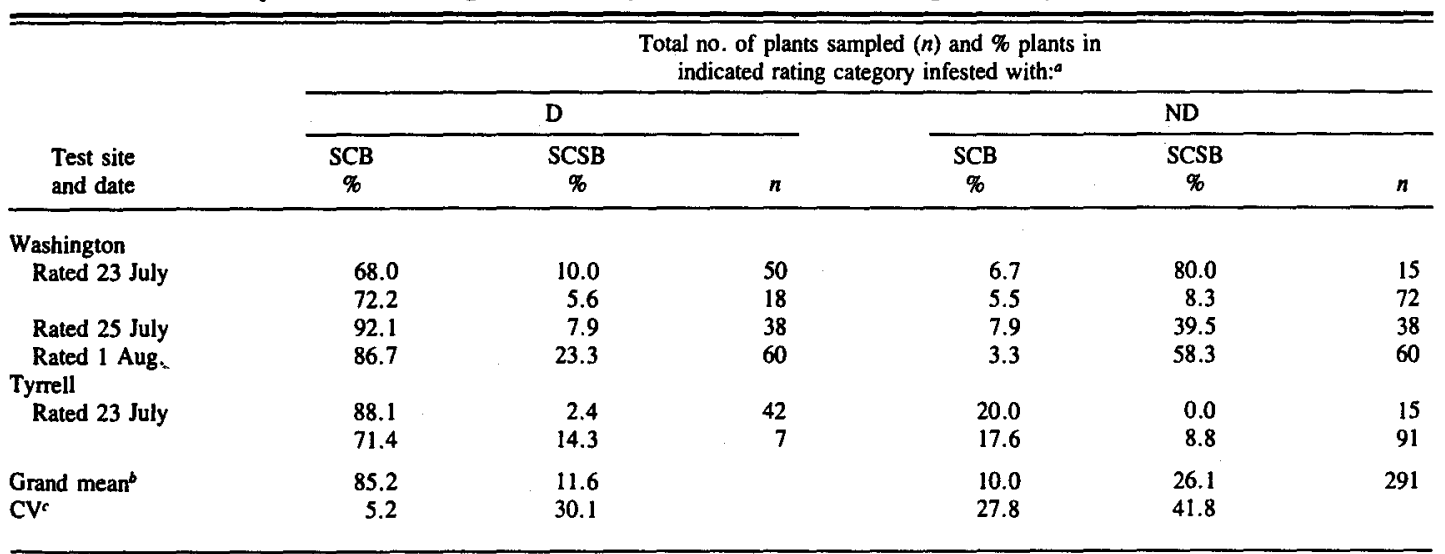

aPercent within a category (i.e., D or ND) and date may add up to over $100 \%$, because of multiple infestations of plants. See text for abbreviations. "Means weighted by $n$.

'CV, coefficient of variation.

of SCSB infestations did not appear to be related consistently to the early death of corn plants.

\section{Discussion}

The most important aspect of this work with respect to SCB management is the demonstrated short period of susceptibility of corn to damage by adult SCB feeding. Adults only damaged corn after feeding on 4-leaf stage or younger plants. Early planting and use of proper agronomic practices to encourage rapid seedling growth will decrease damage by adult feeding to the extent that these practices decrease the amount of overlap in time between adult activity in the spring and susceptible corn plant stages.

In 1980 studies on adult damage potential, average plant damage per plot, as measured on a 0 to 3 damage rating scale, was negatively correlated with average plant height per plot at three dates on 6-, 8-, and 9- to 10leaf stage corn. However, corn grain yield per plot was positively correlated with average damage ratings per plot on 9 July, when corn was at the 9- to 10-leaf stage. One possible explanation of this effect is that corn was planted at high densities in these plots (25 plants per $3.24 \mathrm{~m}^{2}$, equivalent to 12,647 plants per ha), and high early-season damage may have thinned some plots to a more optimal density, allowing surviving plants to increase yield per plot enough to compensate for earlyseason damage. Similar effects may have occurred in 1979 when com was grown at a density of 35 plants per plot (equivalent to 17,706 plants per ha).

The difference in adult damage potential due to SCB sex could be related to several factors. Females are generally larger than males (Vaurie 1951), and their correspondingly longer beak may enable them to reach further into the plant and reach the growing point of the plant. Also, females, because of the metabolic demands of egg production, may require greater food intake than males. In studies of seasonal biology, we found that SCB sex ratio (male-female) was highest in newly emerged adults found in August and September, decreased over winter 
and was lowest at the end of the generation in June. In the period from April to May, when adults cause the most damage, SCB sex ratio (male-female) was ca. 1.0 to $1.5: 1$ (Wright 1981).

Early death of posttasseling corn plants was most consistently associated with SCB larval presence. This trait may be useful in late-summer surveys to identify problem fields before planting the next year so that recommendations can be made relative to crop rotation or insecticide usage. The degree of association of SCB infestations with this trait should be tested before its use can be recommended in other areas. We observed in this study that the number of dying plants increased along a gradient in one field corresponding to increased moisture stress (Wright 1981). It is possible that other pest organisms or physiological imbalances could induce this trait. Although larval SCB infestations were consistently associated with the early death of posttasseling com plants, sublethal effects by adult feeding early in the season cannot be ruled out as a contributing factor. If female SCB predominately fed on plants in which they oviposit, this might produce an association between larval SCB infestations and early death of corn plants without implying causality.

Estimates of yield decrease associated with larval SCB infestations suggested that this stage may be an important pest. However, there are not now any management tactics used to directly affect the insect in this stage. Host plant resistance may be a feasible approach in the future. Also, preliminary studies (Wright 1981) showed that larval survival in corn artificially infested with SCB eggs decreased after corn passed the six-leaf stage. Thus, early planting may decrease larval survival as well as adult damage, but only if conditions are such that optimum seedling development occurs. Further studies are needed to assess the effect of corn plant stage on SCB oviposition behavior, larval survival, and yield reduction in corn.

\section{Acknowledgment}

We thank G. G. Kennedy, F. Gould, and G. C. Rock for review of the manuscript, $M$. Rogerson, N. Whitehurst, and V. W. Modlin for technical assistance, and T. N. Hunt for advice and assistance in the planning and execution of the damage surveys. We are grateful for partial financial support received from the Corn Producers Association of North Carolina and the National Crop Loss Design Committee, USDA-SEA.

\section{REFERENCES CITED}

Durant, J. A. 1981. Southern corn billbug: effect of plant height and billbug population density on injury to corn. J. Ga. Entomol. Soc. 61: 475-478.

Hanway, J. J. 1966. How a com plant develops. Iowa St. Univ. Coop. Ext. Serv. Spec. Rep. 48. 17 pp.

Metcalf, Z. P. 1917. Biological investigation of Sphenophorus callosus Olivier [sic]. N.C. Agric. Exp. Stn. Bull. 13. 123 pp.

Vaurie, P. 1951. Revision of the genus Calendra (formerly Sphenophorus) in the United States and Mexico (Coleoptera: Curculionidae). Bull. Am. Mus. Nat. Hist. 98. 186 pp.

Webster, F. M. 1912. The so-called "curlew bug." USDA Bur. Entomol. Bull. 95. Part IV. pp. 53-71.

Wright, R. J. 1981. The biology and ecology of the southem corn billbug in eastern North Carolina. Ph.D thesis, North Carolina State University, Raleigh. 117 pp. 